\title{
MENINGKATKAN KETERAMPILAN BERPIKIR KRITIS DAN KREATIF SISWA MELALUI PEMBELAJARAN TATA NAMA SENYAWA KIMIA DENGAN MENGGUNAKAN MEDIA PIRINGAN KATION ANION
}

\author{
Herlina ${ }^{1}$, Leny Heliawati ${ }^{2 *}$, Irfan Permana ${ }^{2}$, \\ ${ }^{1}$ Pendidikan IPA, Universitas Pakuan \\ ${ }^{2}$ Program Pascasarjana, Universitas Pakuan \\ Email: leny_heliawati@yahoo.co.id
}

\begin{abstract}
Abstrak: Penelitian ini bertujuan untuk mengetahui sejauh mana pemanfaatan media piringan kation anion dapat membangun keterampilan berpikir kritis dan kreatif siswa pada pembelajaran tata nama senyawa. Metode yang digunakan dalam penelitian ini adalah preeksperimen dengan pre-postest design. Instrumen yang digunakan terdiri dari soal keterampilan berpikir kritis, penilaian observasi keterampilan berpikir kreatif, dan angket respon siswa. Hasil penelitian menunjukkan bahwa pembelajaran yang dikemas dengan model inquiri sesuai dengan tahapan pembelajaran yang direkomendasikan berdasarkan kurikulum 2013, ternyata mampu meningkatkan keterampilan berpikir kritis dan kreatif siswa. Hasil penelitian juga menunjukkan bahwa terdapat korelasi positif antara keterampilan berpikir kritis dengan keterampilan berpikir kreatif dengan korelasi 0,478 (cukup). Siswa juga memberikan respon positif terhadap pembelajaran.
\end{abstract}

Kata Kunci: media, berpikir kritis, pemikiran kreatif, tata nama senyawa

\section{PENDAHULUAN}

Keberhasilan pencapaian pendidikan banyak bergantung pada proses pembelajaran yang berlangsung secara efektif serta melibatkan banyak aktivitas peserta didik. Selain metode mengajar aspek lain yang menonjol adalah penggunaan media pembelajaran sebagai alat bantu mengajar. Kedudukan media pembelajaran sebagai salah satu lingkungan belajar yang diatur oleh guru dengan tujuan mempertinggi proses belajar siswa yang pada gilirannya diharapkan dapat mempertinggi hasil belajar yang dicapainya (Sudjana, 2015).

Ilmu kimia adalah ilmu yang berkenaan dengan karakteristik, komposisi dan tranformasi materi (Mortimer dalam Ashadi, 2009). Menurut Middlecamp \& Kean (1985) ilmu kimia banyak memuat konsep-konsep abstrak seperti simbolsimbol, struktur, reaksi dan proses-proses kimia yang terstrukur. Banyak siswa SMA menganggap mata pelajaran kimia sulit dipelajari, sehingga siswa sudah terlebih dahulu merasa kurang mampu mempelajarinya (Yusfiani \& Situmorang, 2006). Sehingga diperlukan media pembelajaran yang dapat memberikan banyak manfaat, pemahaman, motivasi, dan tidak menganggap kimia itu sulit, tetapi sebagai mata pelajaran yang menyenangkan. 
Peraturan Mendikbud No.64 Tahun 2013 tentang Standar Isi Pendidikan Dasar dan Menengah untuk memenuhi kebutuhan masa depan dan menyongsong Generasi Emas Indonesia Tahun 2045, telah ditetapkan Standar Kompetensi Lulusan yang berbasis pada Kompetensi Abad 21, bahwa pembelajar harus mampu mengembangkan keterampilan kompetitif yang berfokus pada pengembangan keterampilan berpikir tingkat tinggi (higher order thinking skills) yaitu berpikir kritis (critical thinking) dan berpikir kreatif (creative thinking). Tugas guru adalah menciptakan peluang bagi siswa untuk mengembangkan dan meningkatkan keterampilan berpikir kritis dan kreatif sehingga mampu memahami dunia disekitarnya dan membuat keputusan yang baik, meningkatkan kinerja, dan meningkatkan motivasi belajar (Stobaugh, 2013). Guru harus melibatkan peserta didik secara sistematik, memberikan motivasi kepada siswa agar peserta didik mampu mempunyai kemauan belajar lebih giat dan sungguhsungguh. Guru harus dapat menggunakan multi metode dan multi media dalam pembelajaran sehingga peserta didik tidak hanya mengenal fakta, tetapi juga pengetahuan bagaimana prosedur memperoleh fakta tersebut. Guru juga harus memberikan kesempatan kepada peserta didik untuk melakukan kegiatan belajar sesuai kapasitasnya, menciptakan iklim yang baik dan menyenangkan (Sudjana, 2015). Oleh karena itu diperlukan media pembelajaran berupa alat peraga/ praktikum yang tepat.

Penggunaan media pembelajaran yang inovatif juga dapat memfasilitasi pelaksanaan pembelajaran seperti yang diinginkan PP No.32 Tahun 2013 pasal 19 ayat (1) yang menyebutkan bahwa kegiatan pembelajaran pada satuan pendidikan diselenggarakan secara interaktif, inspiratif, menyenangkan, menantang dan memotivasi peserta didik. Penggunaan media pembelajaran berpotensi untuk membantu meningkatkan performa akademik peserta didik berupa hasil belajar pada ranah kognitif (Chuang \& Chen, 2007, Jabbour, 2014, Anugrah et al 2015), motivasi dan minat belajar peserta didik (Habibi \& Prabowo, 2015).

Berdasarkan uraian masalah tersebut maka penelitian ini berusaha memanfaatkan suatu media piringan kation untuk guru dalam proses pembelajaran dalam meningkatkan keterampilan berpikir kritis dan kreatif siswa pada materi tata nama senyawa.

\section{METODE}

Metode yang digunakan dalam penelitian ini adalah metode preeksperimen dengan 1 kelas sebagai kelas eksperimen. Produk inovatif yang telah dikembangkan dalam penelitian sebelumnya berupa media piringan kation anion sudah melalui penilaian validasi beberapa ahli sehingga layak digunakan dalam pembelajaran tata nama senyawa. Penelitian ekperimen dengan model tes awal keterampilan berpikir kritis (KBK) dan tes akhir (KBK). Pengaruh suatu 
perlakuan diputuskan berdasarkan perbedaan antara tes awal KBK dan tes akhir KBK. Sebelum perlakuan eksperimen kelompok dilakukan tes awal KBK. Setelah ekperimen diberikan tes akhir KBK untuk melihat prestasi yang diperoleh. Skor rata-rata yang diperoleh dibandingan dari skor rata-rata tes awal KBK dan skor rata-rata tes akhir KBK. Ketika hasilnya skor tes akhir KBK secara signifikan lebih tinggi dari tes rata-rata skor awal KBK, maka dapat disimpulkan bahwa pembelajaran efektif.

Prosedur penelitian ini dideskripsikan melalui alur penelitian yang terdiri dari tahapan persiapan, tahapan pelaksanaan, dan tahapan akhir. Tahapan tersebut dijelaskan sebagai berikut:

\section{Tahap Persiapan}

Kegiatan yang dilakukan pada tahap ini meliputi:

a. Studi pendahuluan bertujuan untuk mencari permasalahan yang muncul ketika proses pembelajaran baik pada siswa maupun guru. Pada tahap ini dilakukan pengamatan terhadap aktivitas siswa selama belajar kimia dan metode mengajar yang digunakan guru kimia didalam kelas.

b. Studi literatur, bertujuan untuk mendapatkan teori dan konsep yang berkaitan dengan materi yang dipilih agar dapat sesuai dengan Kompetensi Dasar (KD) yang ditentukan dalam kurikulum. Hasil dari studi literatur ini kemudian akan dijadikan acuan untuk mendesain Rencana Pelaksanaan Pembelajaran, serta perangkat yang diperlukan dalam penelitian ini.

c. Menentukan sekolah yang akan dijadikan tempat pelaksanaan penelitian

d. Menentukan sampel penelitian

e. Membuat proposal

f. Perancangan instrumen soal pretest dan postest disesuaikan dengan indikator keterampilan berpikir kritis

g. Perancangan instrumen observasi keterampilan berpikir kreatif angket respon siswa.

h. Uji instrumen penelitian, uji instrumen tes pilihan ganda beralasan dilakukan untuk mengetahui validitas, reliabilitas, tingkat kesukaran dan daya pembeda instrumen penelitian.

i. Menganalisis hasil uji instrumen, kemudian menentukan soal yang layak untuk dijadikan instrumen penelitian.

\section{Tahap Pelaksanaan}

Setelah tahap persiapan di atas dilaksanakan, masuk ke tahap berikutnya yaitu tahap pelaksanaan. Implementasi dari penelitian ini dilakukan di salah satu madrasah aliyah yang berada di Kota Bogor. Sampel yaitu kelas X IPA dengan 
jumlah siswa sebanyak 37 siswa pada uji coba. Dari 37 siswa dibagi 6 kelompok, tiap kelompok terdiri 6-7 siswa. Sebelum perlakuan diberikan, 30 menit pertama siswa diminta mengerjakan soal pretest materi tata nama senyawa yang telah dipelajari sebelumnya, Selanjutnya siswa praktikum dengan menggunakan alat piringan kation dan anion dengan waktu 60 menit untuk mencari dan mengolah data hasil percobaan, serta membuat kesimpulan. Pada saat praktikum, guru yang mengajar yaitu peneliti dan 2 guru kimia sebagai observer, mengisi lembar observasi penilaian keterampilan berpikir kreatif ketika siswa menggunakan media piringan kation-anion. Sebelum pembelajaran berakhir yaitu 30 menit terakhir siswa diberikan soal posstest dan mengisi angket respon siswa terhadap media yang dipakai .

\section{Tahap Penyelesaian}

Pada tahap ini, peneliti mengolah data dan membuat kesimpulan hasil penelitian. Penelitian ini mengukur keterampilan berpikir kritis. Sehingga digunakan tes evaluasi yang diujicobakan terlebih dahulu untuk mengetahui validitas, tingkat kesukaran, daya beda, dan reliabilitasnya. Media yang digunakan adalah media yang telah divalidasi oleh 2 orang ahli dan 3 guru kimia dengan kategori sangat baik. Selain mengukur keterampilan berpikir kritis mengunakan tes evaluasi pilihan berganda beralasan. Penelitian ini juga mengukur keterampilan berpikir kreatif dengan menggunakan observasi penilaian keterampilan berpikir kreatif siswa oleh 2 observer. Kemudian juga dilakukan pemberian angket kepada siswa untuk mengetahui respon siswa mengenai penggunaan media piringan kation anion dalam pembelajaran kimia dengan materi tata nama senyawa. Untuk mengetahui peningkatan keterampilan berpikir kreatif dilakukan perhitungan statistik dengan menghubungkan keterampilan berpikir kreatif dan keterampilan berpikir kritis siswa.

\section{HASIL DAN PEMBAHASAN}

Pada penelitian ini menetapkan dan mendefinisikan syarat syarat berupa analilis KI (Kompetensi Inti), KD (Kompetensi Dasar), dan IPK (Indikator Pencapaian Kompetensi) materi tata nama senyawa, serta penelitian pendahuluan yang terkait dengan penggunaan media dalam pembelajaran. Pendefinisian juga dilakukan melalui wawancara kepada guru dan peserta didik yang bertujuan untuk mencari permasalahan yang muncul ketika proses pembelajaran baik pada siswa maupun guru. Berdasarkan wawancara guru bahwa penggunaan media/alat pembelajaran dapat membantu anak dalam memahami materi kimia. Pada materi tata nama senyawa belum pernah digunakan media/alat yang membantu pembelajaran. Materi tata nama senyawa mempunyai nilai yang masih dibawah KKM karena siswa tidak hafal nama unsur/ion, sulitnya mengingat nama-nama senyawa poliatom dan kurang bisa membedakan unsur logam dan non logam. 
Materi tata nama senyawa bersifat abstrak sehingga siswa sulit untuk memahaminya sehingga butuh alat yang membuat penyampaian materi ini lebih menarik dan meningkatkan rasa keingintahuan siswa untuk belajar. Berdasarkan hasil wawancara juga bahwa penggunaan alat peraga/praktikum saat mengajar materi tata nama dapat memunculkan kemampuan berpikir kritis dan kreatif siswa

Peneliti melakukan beberapa langkah yaitu memilih dan menetapkan sub bab materi tata nama senyawa, kemudian menyiapkan media pembelajaran yang cocok untuk mendukung proses pembelajaran materi tata nama senyawa. Salah satu metode pembelajaran yang dapat meningkatkan keterampilan berpikir kritis dan kreatif adalah dengan metode eksperimen/inquiri. Media piringan kation anion yang digunakan dalam praktikum adalah seperti tampak pada Gambar 1 . Media ini terdiri dari piringan CD Kation, CD Anion dan puzzle anion kation. CD kation anion ini berjumlah $4 \mathrm{CD}$ yang terdiri dari $\mathrm{CD}$ kation 2 buah dan $\mathrm{CD}$ anion 2 buah, dimana masing masing CD berisi 12 kation dan anion. CD ini terbuat dari CD bekas yang diberi label nama-nama kation dan anion dengan warna yang disesuaikan pada puzzle, sedangkan puzzle terbuat dari busa foam art, yang dibuat berdasarkan nama-nama kation dan anion dengan warna sesuai warna yang ada pada piringan $C D$ kation dan anion untuk masing-masing senyawa ion. Pada masing-masing alat terdapat $4 \mathrm{CD}$ dengan $2 \mathrm{CD}$ senyawa kation dan $2 \mathrm{CD}$ senyawa anion.

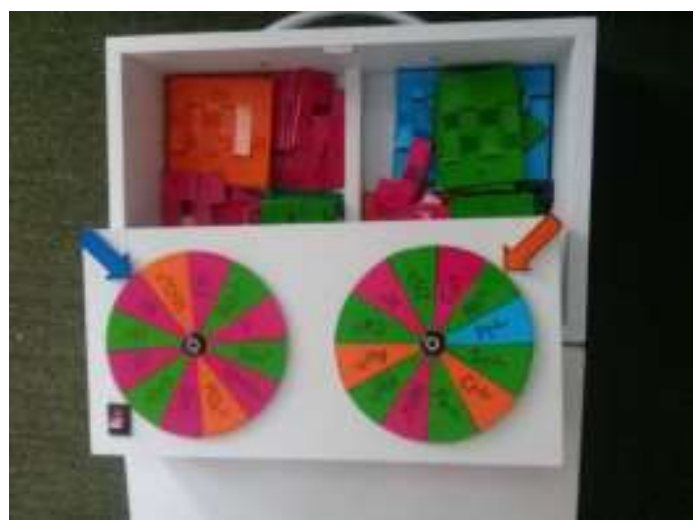

Gambar 1. Media Piringan Kation Anion

Media piringan kation anion telah dilakukan validasi oleh tim ahli/dosen dan guru kimia. Hasil validasi oleh ahli mempunyai kriteria sangat baik $(93,75$ $\%)$. Hasil validasi alat oleh guru juga berada dalam kriteria sangat baik $(90,2 \%)$. Sehingga media piringan kation anion tersebut layak digunakan sebagai media pembelajaran siswa.

Media piringan kation-anion ini merupakan salah satu contoh media pembelajaran yang dapat dipadukan dengan permainan. Permainan dapat 
digunakan sebagai media pembelajaran yang murah dan menyenangkan, dan sebagai alat pembelajaran yang efektif. Menurut Antunes, et al (2012) permainan seperti domino, kartu remi, tebak kata, puzzle mencari kata (charades) dapat diterapkan dan digunakan untuk konsep terkait dengan penamaan senyawa organik, siswa merasa senang dan dapat mencapai tujuan dalam pembelajaran. Hal ini sesuai dengan hasil pra penelitian Fitriany dan Sukarmin (2016) menunjukkan bahwa 94\% siswa menyukai permainan dalam pembelajaran.

Langkah selanjutnya adalah peneliti menindaklanjuti dengan menyiapkan perangkat pendukung percobaan yaitu lembar kerja praktikum siswa. Pada tahap peneliti juga membuat rancangan instrumen soal pretest dan postest untuk mengukur keterampilan berpikir kritis siswa bisa meningkat setelah menggunakan media piringan kation anion dan instrumen penilaian observasi berpikir kreatif untuk mengetahui sejauh mana keterampilan berpikir kreatif siswa.

Hasil penelitian menunjukkan terjadi perbedaan antara hasil pretest siswa sebelum mendapatkan treatment (rata-rata $=36,57$ ) dan postest (rata-rata = 66,22). Terjadi peningkatan $N$-Gain sebesar $46,33 \%$ berada pada kriteria sedang. Peningkatan rata-rata keterampilan berpikir kritis pada nilai pretest dan postest sesudah treatment ditunjukkan pada gambar 2.

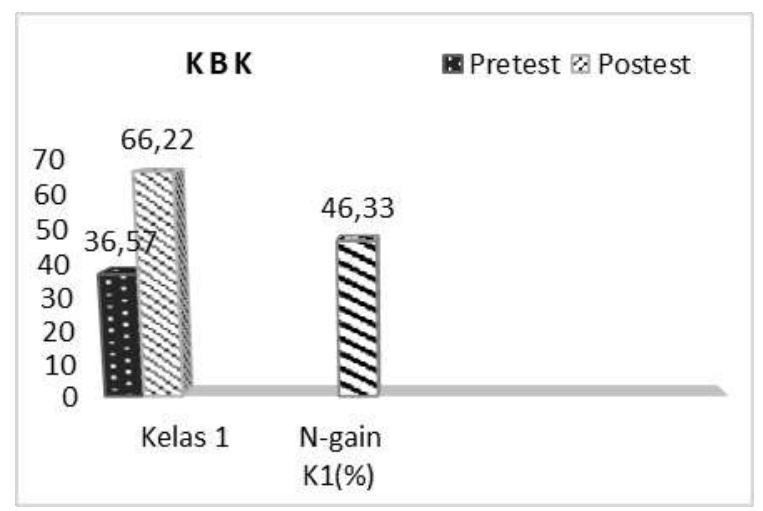

Gambar 2. Peningkatan keterampilan berpikir kritis siswa

Hasil perolehan rata-rata $N$-gain berada pada kriteria sedang, oleh sebab itu perlu dianalisis signifikasi peningkatannya menggunakan uji statistik paired sampel t-test dengan SPSS versi 23. Sebagai uji prasyarat dilakukan uji normalitas dan homogenitas. Hasil uji normalitas baik data pretest maupun postest adalah Asymp Sig (2-tailed) 0,200 ( $\mathrm{p}>0,05)$, hal ini berarti bahwa data nilai berdistribusi normal.

Selanjutnya dilakukan uji homogenitas Levene Statistik dengan SPSS versi 23 pada data pretest dan posttest hasil uji homogenitas menyatakan bahwa nilai signifikasi sebesar 0,368 ( $\mathrm{p}>0,05$ ), hal ini menunjukan bahwa distribusi data homogen. Data berdistribusi normal maka untuk mengetahui signifikasi 
perbedaan nilai pretest dan posttest dilakukan uji paired sampel t-test. Hasil uji paired sampel t-test sebesar $0,000(\mathrm{p}<0,05)$ yang artinya terdapat perbedaan yang signifikan keterampilan berpikir kritis siswa dilihat dari hasil pretest dengan posttest pada pembelajaran kimia materi tata nama senyawa. Hasil analisis data ini dapat diartikan bahwa media piringan kation anion yang digunakan sebagai media selama proses pembelajaran dapat meningkatkan keterampilan berpikir siswa. Hal ini sejalan dengan penelitian Lisdianto et al (2015) yang menyatakan bahwa media ICM (Integrated Contextual Module) yang merupakan modul pembelajaran elektronik interaktif efektif meningkatkan kreatifitas dan kemampuan berpikir kritis siswa. Pada penelitian Hardianti et, al (2014) menyatakan model pembelajaran kooperatif tipe make a match yang menggunakan media kartu pada topik penaman senyawa dan persamaan reaksi memberikan pengaruh yang lebih baik terhadap hasil belajar dan keterampilan berpikir kritis siswa dan terdapat peningkatan aktivitas siswa dan guru dalam proses pembelajaran. Oleh karena itu mengingat pentingnya pengembangan media praktikum untuk meningkatkan keterampilan berpikir kritis siswa maka perlu kiranya seorang guru menetapkan metode pembelajaran yang tepat sesuai dengan materi yang diajarkan. Untuk mengetahui lebih rinci perbedaan peningkatan dari ke lima indikator keterampilan berpikir kritis siswa dapat dilihat pada table 1. Berdasarkan Table 1 peningkatan $N$-gain pada masing-masing indikator berpikir kritis siswa terlihat bahwa indikator memberikan penjelasan sederhana berada pada kriteria tinggi, (73\%), indikator keterampilan berpikir kritis yang berada pada kriteri sedang meliputi indikator menentukan keterampilan dasar (44\%), menyimpulkan (44\%), memberikan penjelasan lebih lanjut (42\%) dan mengatur strategi dan taktik $(36 \%)$.

Tabel 1. Hasil pretest dan postest keterampilan berpikir kritis dengan 5 kelompok indikator.

\begin{tabular}{llccc}
\hline \multirow{2}{*}{ Ino } & Indikator KBK & \multicolumn{3}{c}{ Nilai rata-rata kelas } \\
\cline { 3 - 5 } & pretest & postes & N-Gain \\
\hline $\mathbf{1}$ & $\begin{array}{l}\text { Memberikan penjelasan } \\
\text { sederhana }\end{array}$ & 46.9 & 85.7 & $73 \%$ \\
\hline $\mathbf{2}$ & $\begin{array}{l}\text { Menentukan } \\
\text { keterampilan dasar }\end{array}$ & 36.4 & 64.5 & $44 \%$ \\
\hline $\mathbf{3}$ & Menyimpulkan & 36.7 & 64.7 & $44 \%$ \\
\hline $\mathbf{4}$ & $\begin{array}{l}\text { Memberikan penjelasan } \\
\text { lebih lanjut }\end{array}$ & 34.8 & 62.1 & $42 \%$ \\
\hline $\mathbf{5}$ & $\begin{array}{l}\text { Mengatur strategi dan } \\
\text { taktik }\end{array}$ & 32.7 & 57.2 & $36 \%$ \\
\hline
\end{tabular}


Table 1. Memperlihatkan bahwa terdapat perbedaan hasil pretest dan postest pada setiap indikator keterampilan berpikir kritis siswa. Hasil analisis menunjukkan bahwa indikator memberikan penjelasan sederhana memiliki $\mathrm{N}$-gain paling tinggi dibandingkan 4 indikator yang lainnya yaitu sebesar $73 \%$. Hal ini menunjukkan bahwa selama proses pembelajaran menggunakan metode eksperimen, siswa dapat mendeskripsikan aturan penamaan senyawa biner, dapat memberikan nama senyawa pada percobaan dengan menggunakan alat piringan kation anion. Tingginya kemampuan berpikir kritis siswa pada kelompok indikator memberikan penjelasan sederhana dikarenakan pada kegiatan pembelajaran praktikum dengan menggunakan lembar kerja siswa, siswa untuk terbiasa menuliskan apa yang diketahui dan apa yang ditanyakan sehingga memudahkan siswa memahami soal. Pada proses ini siswa juga melakukan pengumpulan data senyawa-senyawa yang akan terbentuk dengan menggunakan alat piringan kation anion. Dengan menggunakan alat piringan kation anion siswa dapat menjelaskan proses pembentukan suatu senyawa ion berdasarkan bilangan oksidasi atau muatan yang dimiliki dari masing-masing senyawa ion. Siswa juga dapat menuliskan suatu senyawa terbentuk berdasarkan tata nama penulisan senyawa dimulai dari kation yang merupakan senyawa logam dan diikuti oleh anion yang merupakan senyawa non logam yang diakhiri oleh akhiran-ida. Dan untuk senyawa poliatom anion, siswa dengan melakukan percobaan menggunakan media piringan kation anion siswa belajar untuk dapat menghafalkan nama-nama anion poliatom yang terasa sulit jadi lebih mudah. Dengan demikian hal tersebut menunjukkan bahwa melaksanakan kegiatan praktikum dapat mengorientasikan siswa pada kelompok indikator memberikan penjelasan sederhana mampu membentuk keterampilan berpikir kritis siswa. Hal ini sejalan dengan penelitian Hartati (2010) yang menyatakan pengembangan alat peraga gesek dengan melaksanakan kegiatan praktikum dapat meningkatkan keterampilan berpikir kristis peserta didik pada mata pelajaran fisika. Sedangkan pada hasil analisis data juga menunjukkan bahwa indikator membangun keterampilan dasar, menyimpulkan, dan memberikan penjelasan lebih lanjut menunjukan peningkatan nilai $N$-gain yang hampir sama dimana terjadi perbedaan yang cukup signifikan sebelum dan sesudah treatment. Hal ini berarti siswa mampu menambah konsep baru untuk mengungkap dan memahami fenomena yang terjadi dalam kehidupan sehari. Pada pembelajaran dengan metode praktikum, peneliti membimbing siswa menyelesaikan lembar kerja siswa dan memberikan penjelasan pada pada penggunaan media piringan kation anion. Namun pada saat posttest meskipun hampir seluruh siswa menyelesaikan lembar kerjanya masih banyak siswa yang hanya mengerjakan sebagian reaksi kimianya dan tanpa disetarakan. Tidak disetarakan reaksi kimia atau hanya sebagian menuliskan reaksi kimia tidak lepas dari pendapat Ennis (Susanto, 2015) bahwa berpikir kritis sebagai suatu proses 
berpikir sehingga dari reaksi kimia tersebut tersimpan dalam memori mereka dan tidak mereka tuangkan kedalam jawaban. Buktinya meskipun mereka tidak memberikan reaksi kimia secara lengkap, mereka masih bisa menyelesaikan posttest dengan strategi yang tepat. Hal ini sejalan dengan Silverman dan Smith dalam Filsaime (2008), menyatakan yaitu salah satu hal seseorang dikatakan menunjukkan berpikir kritis apabila mampu mensintesis informasi sampai pada kesimpulan yang masuk akal. Dalam menyelesaikan posttest strategi yang digunakan hampir seluruh siswa sudah sangat jelas dan benar mau dibawa kemana arah penyelelesaian. Namun hal yang luput dari perhatian hampir seluruh siswa adalah ketidaktelitian mereka dalam menjawab alasan, sehingga tidak sedikit mereka yang benar dalam melakukan penyelesain namun kesalahan dalam memilih alasan jawaban. Untuk indikator menyimpulkan, kemampuan berpikir kritis indikator ini sedang dikarenakan siswa dalam menyimpukan masalah yang diberikan sudah sesuai dengan konteks soal, ada sebagian siswa yang tidak tepat dalam membuat kesimpulan. Salah satu penyebabnya adalah dalam menjawab alasan kesimpulan tersebut. Meskipun dikategorikan sedang, hal ini bukan berarti media piringan kation anion tidak mampu membentuk kemampuan berpikir kritis siswa karena dalam menjawab soal posttest siswa harus berpikir kritis dalam menganalisis soal yang sesuai dengan konteks soal.

Penelitian ini juga ingin mengetahui bagaimana keterampilan berpikir kreatif siswa setelah menggunakan media piringan kation dalam pembelajaran tata nama senyawa. Untuk mengukur variabel keterampilan berpikir kreatif siswa, peneliti menggunakan observasi oleh 2 guru kimia.

Sedangkan hasil penilaian berpikir kreatif berdasarkan observasi penilaian berpikir kreatif yang dilakukan oleh 2 observer guru kimia diperoleh berpikir lancar yang memperoleh nilai tertinggi.

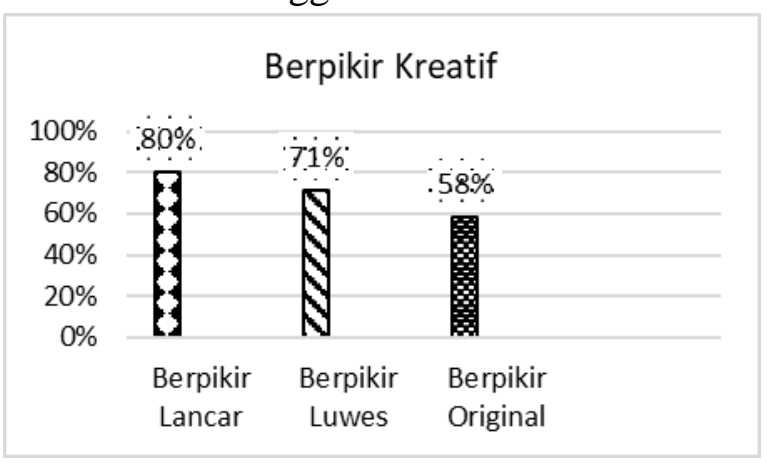

Gambar 3. Hasil Observasi Penilaian Berpikir Kreatif

Berdasarkan hasil analisis observasi penilaian berpikir keterampilan berpikir kreatif siswa dikategorikan baik (69\%). Hasil observasi penilaian berpikir lancar dikategorikan sangat baik (80\%). Hal ini dikarenakan dengan metode ekperimen dan penggunaan alat media piringan kation anion siswa banyak yang terlibat aktif 
dalam pembelajaran mereka berusaha bersama dalam menyelesaikan masalah bersama, yang diberikan pada lembar kerja siswa. Praktikum ini dibagi atas 6 kelompok dan masing-masing kelompok berusaha mengerjakan dan menyelesaikan dengan cekatan. Hal ini juga sesuai dengan penelitian Nurlaela (2017) menunjukkan bahwa penggunaan kartu kation anion dapat meningkatkan aktifitas siswa pada writing activities, visual activities, mental activities dan motor activities pada materi tata nama senyawa. Pada penelitian yang dilakukan oleh Liu dan Chen (2013) menyatakan bahwa para siswa menunjukkan sikap positif terhadap penggunaan permainan kartu pendidikan dalam pembelajaran sains dan juga menunjukkan efektivitas permainan kartu pendidikan yang diusulkan dalam meningkatkan pengetahuan ilmiah siswa pada materi transportasi dan energi. siswa juga biasa mengajukan banyak pertanyaan karena merasa penasaran dengan materi yang disampaikan oleh guru dan memberikan sejumlah pertanyaan atau pendapat untuk dapat menyelesaikan masalah. Pada kegiatan praktikum siswa terlibat aktif dalam pembelajaran dan bekerja lebih cepat menggunakan alat piringan kation anion. Kegiatan paraktikukm ini secara tidak disadari siswa telah melaksanakan proses perilaku kreatif dan secara perlahan kemampuan berpikir kreatifnya akan berkembang. Hal ini sejalan dengan pernyataan dari Widayanto (2009) bahwa semakin tinggi keterlibatan siswa dalam kegiatan praktikum semakin tinggi pencapaian pemahaman dan keterampilan proses sains siswa. Pada penelitian ini keterampilan proses sains yang digunakan adalah proses-proses yang mengacu pada proses berpikir kreatif siswa. Pada keterampilan berpikir luwes siswa dikategorikan baik (71\%). Hal ini dikarenakan siswa agak kurang mampu dalam menguraikan permasalahan yang ada dilembar kerja siswa seperti menguraikan kembali reaksi kimia yang mereka dapatkan dalam pembentukan suatu senyawa. Dalam hal menjawab soal pada lembar kerja siswa secara beragam siswa cukup sulit hanya beberapa saja yang dapat mengerjakannya. Ada siswa dapat mengajukan banyak cara untuk menyelesaikan suatu masalah dan memikirkan banyak cara untuk menyelesaikan masalah. Hal ini dibuktikan dengan praktikum menggunakan piringan kation anion siswa banyak mempraktikan sesuai dengan keinginan mereka. Seperti memutarkan piringan kation anion sebanyak jumlah yang diperintahkan pada lembar kerja siswa kemudian menyususun rangkaian puzzle satu persatu untuk dapat membentuk suatu senyawa kemudian memberikan nama senyawa terbentuk. Karena siswa belajar lebih efektif jika menggunakan lingkungan atau peralatan yang ada di sekitarnya, sehingga dapat merangsang rasa ingin tahu, melakukan pengamatan, membuat kesimpulan, dan mendapatkan pengalaman melalui proses ilmiah (Nuriyanah, 2015). Keterampilan berpikir kreatif orisinil mempunyai nilai yang paling rendah dengan dikategorikan cukup baik (58\%). Hasil ini dikarenakan siswa kurang mampu dalam menghasilkan gagasan yang baru, mengembangkan jawaban dan 
memberikan jawaban yang lain dari yang biasa. Hal ini dikarenakan siswa tidak terbiasa melakukan, dan takut akan jawabannya salah karena tidak sama dengan temanya, dan ketidakpercayaan diri menyelesaikan soal-soal yang diberikan. Hal ini sesuai dengan Riza (1999 dalam Bacanli et al, 2011) bahwa faktor yang menghambat berpikir kreatif adalah rasa malu, takut gagal, disalahkan, kurangnya toleransi dan terlalu banyak mengkritik diri sendiri. Berpikir kreatif rendah dapat terjadi karena berbagai macam faktor yang melatarbelakanginya. Menurut Santrock (2004) menyatakan bahwa hasil tersebut dapat terjadi bukan karena faktor kecerdasan akan tetapi karena faktor gaya belajar dan berpikir. Ada pula pendapat lain yang menyebutkan penyebab terjadinya hasil tes tersebut dikarenakan pengaruh yang muncul dari faktor intern siswa yang meliputi gangguan atau kekurangmampuan psikofisik siswa baik yang bersifat kognitif, afektif, maupun psikomotor, serta faktor ekstern siswa yang meliputi semua situasi dan kondisi lingkungan sekitar yang tidak mendukung aktivitas belajar siswa seperti lingkungan keluarga, lingkungan masyarakat dan lingkungan sekolah (Syah, 2009).

Untuk mengetahui peningkatan keterampilan berpikir kreatif siswa pada penelitian ini dihitung dengan mengetahui hubungan antara angket keterampilan berpikir kreatif dan hasil keterampilan berpikir kritis siswa menggunakan rumus regresi liner dengan mencari nilai korelasinya (r). Berdasarkan perhitungan menggunakan SPSS versi 23 diperoleh rumus regresi linier sederhana $\mathrm{Y}=40.938$ $+0,453 \mathrm{X}$. yang artinya keterampilan berpikir kritis (Y) berpengaruh positif terhadap keterampilan berpikir kreatif siswa. Berdasarkan output diketahui nilai signifikasi (Sig) sebesar 0,000 lebih kecil dari probabilits 0,05 sehingga dapat disimpulkan bahwa H0 ditolak dan Ha diterima yang berarti bahwa "Ada Pengaruh KBKf (X) terhadap KBK (Y). Berdasarkan output juga diketahui nilai t hitung sebesar 5,497. Nilai t hitung sebesar 5,497 lebih besar dari t tabel sebesar 2,035, sehingga dapat disimpulkan bahwa H0 ditolak dan Ha diterima, yang berarti bahwa "Ada Pengaruh KBKf (X) terhadap KBK (Y). Untuk mengetahui besarnya pengaruh $\mathrm{KBKf}(\mathrm{X})$ terhadap $\mathrm{KBK}(\mathrm{Y})$ dalam analisis regresi linier sederhana, dapat berpedoman pada nilai R Square arau R2 yang terdapat pada output SPSS bagian Model Summary. Dari output diketahui R Square sebesar 0,478. Nilai ini mengandung arti bahwa pengaruh KBKf (X) terhadap KBK (Y) adalah sebesar 47,8 \% dengan kriteria cukup tinggi. Sehingga dalam penelitian ini dengan adanya pengaruh keterampilan berpikir kreatif terhadap keterampilan berpikir kritis siswa maka terjadi peningkatan keterampilan berpikir kreatif siswa dengan menggunakan media piringan kation anion.

Efektifitas media piringan kation anion dapat pula diketahui dari respon siswa Respon siswa terhadap media diperoleh dengan menyebarkan angket 
kepada 37 siswa kelas X IPA 5. Adapun hasil respon siswa dapat dilihat pada Gambar 4.

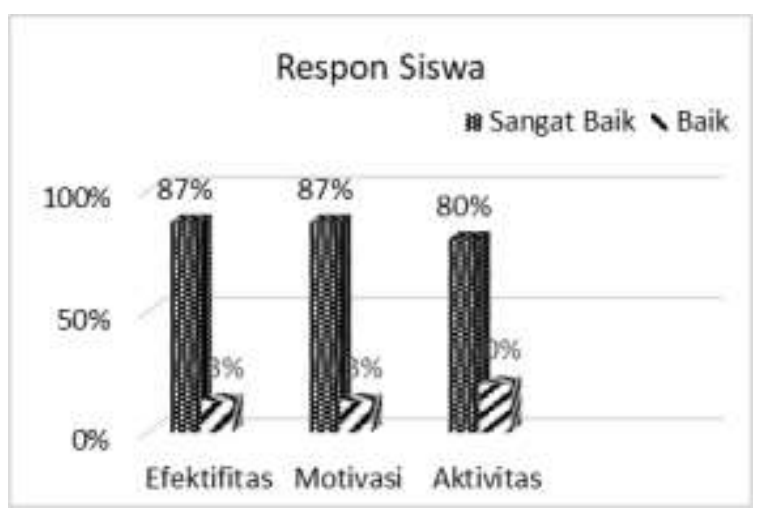

Gambar 4. Hasil Respon Siswa Terhadap Media Piringan Kation Anion

Respon siswa sebagai pengguna media piringan kation anion perlu diperhatikan. Adapun hasil respon siswa terhadap media piringan kation anion pada Gambar 5. dengan kategori sangat baik, rata-rata yaitu sebesar 85\%. Hasil respon siswa dianggap sangat baik dan layak jika persentasenya diatas $80 \%$ (Arikunto, 2012). Hal ini menunjukkan hasil penggunaan media piringan kation anion pada siswa layak digunakan dalam pembelajaran. Siswa menyukai media yang menarik dan warna-warni. Pada pembelajaran dengan menggunakan metode eksperimen siswa sangat antusias dan dapat mengikuti praktikum dengan baik. Sesuai dengan hasil penelitian Susanti dan Lutfi (2014) bahwa pengembangan permainan tradisional jamuran sebagai media pembelajaran tata nama senyawa dapat meningkatkan aktivitas siswa dan ketuntasan belajar yang maksimal. Hidayanti dan Wuryandari (2012) menyatakan bahwa minat siswa dalam penerapan media di sekolah tinggi, dapat membuat siswa benar-benar belajar, menciptakan suasana belajar yang menyenangkan dan membuat belajar lebih mudah bagi siswa untuk memahami topik yang disajikan

\section{PENUTUP}

Pemanfaatan media piringan kation anion sangat mendukung peningkatan keterampilan berpikir kritis dan keterampilan berpikir kreatif siswa. Pembelajaran yang dikemas dengan model inkuiri sesuai dengan tahapan pembelajaran yang direkomendasikan dari kurikulum 2013, ternyata mampu meningkatkan keterampilan berpikir kritis dan kreatif siswa. Hasil penelitian juga menunjukan bahwa terdapat korelasi positif antara pembelajaran keterampilan berpikir kritis dengan berpikir kreatif dengan korelasi 0,478 (cukup). Siswa menberikan respon positif terhadap pembelajaran menggunakan media piringan kation anion 


\section{REFERENSI}

Ashadi, A. 2009. Kesulitan Belajar Kimia Bagi Siswa Sekolah Menengah. Pidato disampaikan pada pengukuhan Guru Besar FKIP UNS pada tanggal 20 Agustus 2009. Diakses dari https://library.uns.ac.id/kesulitan-belajar-kimiabagi-siswa-sekolah-menengah/

Antunes, M, M.A.R. Pacheco, and M. Giovanela. (2012). Design and Implementasi of an Educational Game for Teaching Chemistry in Higher education. Journal of Chemical Education, 89 (4), 2-3.

Anugrah, M.I, Serevina, V, Nasbey, H. (2015). Pengembangan Alat Praktikum Medan Magnet sebagai Media Pembelajaran Fisika SMA. E-Journal, 4(2), 125-130.

Bacanli. H, Dombayci. M.A, Demir. M, Tarhan. S. (2011). Quadruple Thinking: Creative Thinking. Procedia Social and Behavioral Sciences, 12, 536-544.

Chuang, T. Y \& Chen, W. F. 2007. Effect of Digital Games on Children's Kognitif Achievement. Journal of Multimedia, 2, 27-30.

Filsaime, D.K. (2008). Menguak Rahasia Berpikir Kritis dan Kreatif. Jakarta: Prestasi Pustakarya.

Fitriany \& Sukarmin. (2016). Development of PAC Chemisry Game as an Instruksional Media in Chemical Nomenclature. Unesa Journal of Chemical Education, 5(1), 42-50

Habibi, F \& Prabowo. (2015). Pengembangan Alat Peraga Pengukuran Taraf Intensitas Bunyi Berbasis Visual Analyser Sebagai Media Pembelajaran Fisika Pokok Bahasan Bunyi. Jurnal Inovasi Pendidikan Fisika, 4(2), 169175

Hardianti, T. Pursitasari, I. D \& Tangkas. (2014). Model Pembelajaran Koperatif Tipe Make a Math pada Topik Penamaan Senyawa dan Persamaan Reaksi di kelas X SMA Negeri 1 Dampelas. Jurnal Akad Kimia, 3, (4), 183-191.

Hartati, B. (2010). Pengembangan Alat Peraga Gaya Gesek untuk Meningkatkan Keterampilan Berpikir Kritis Siswa SMA. Jurnal Pendidikan Fisika Indonesia, 6, 128-132

Hidayati. N adan Wuryandari. A.I. (2012). Media Design for Learning Indonesian in Junior High School Level. Procedia Social and Behavioral Sciences, 67, 490-499.

Jabbour, K.K (2014). An Analisis of the Effect of Mobile Learning on Lebanse Higher Education. Journal Informatics in Education, 13(1), 1-15

Kemendikbud. (2013). Permendikbud No.64 Tahun 2013 tentang Standar Isi Pendidikan Dasar dan Menengah. Jakarta.

Lisdianto, (2015). Pengembangan Integrated Contextual Module (ICM) untuk meningkatkan kreatifitas dan kemampuan berpikir kritis siswa SMK pada pokok bahasan sifat melanika bahan. Jurnal Inkuiri , 4, 129-134.

Liu, E Z Feng \& Chen, P K. (2013). The Effect of Game-Based Learning on Student' Learning Performance in Science Learning-a Case of 
“Conveyence Go". Journal Procedia Social and Behavioral Science., 103, 1044-1051

Middlecamp, C, \& Kean, E. (1985). Panduan Belajar Kimia Dasar. Jakarta: PT. Gramedia.

Nurlaela, (2017). Penggunaan Kartu Kation Anion dengan Metode Estafet untuk Meningkatkan Aktivitas siswa pada Tata Nama Senyawa. Makalah Paralel, ISBN: 978-6602-73159-8.

Nuriyanah, S. (2015). Pengembangan Kemampuan Berpikir Kreatif Siswa Melalui Praktikum sederhana. Skripsi Universitas Negeri Semarang.

Susanti \& Lutfi. (2014). Pengembangan permainan jamuran sebagai media pembelajaran tata nama senyawa di kelas X SMA. Journal of Chemical Education, 3(2), 279-287.

Santrock, Jhon W. (2004). Psikologi Pendidikan. Jakarta: Kencana.

Stobaugh, R. (2013). Assessing Critical Thinking in Middle and High Schools. New York London: Routledge Taylor \& Francis Group.

Susanto, A. (2015). Teori Belajar dan Pembelajaran di Sekolah Dasar. Prenadamedia Group, Jakarta.

Syah, Muhibbin. (2009). Psikologi Belajar. Jakarta: Rajawali Pers.

Sudjana, D. (2015). Strategi Pembelajaran. Bandung: Falah Production

Widayanto. (2009). Pengembangan Keterampilan Proses dan Pemahaman Siswa Kelas X melalui KIT Optik. Jurnal Pendidikan Fisika Indonesia, 5, 1-7.

Yusfiani \& Situmorang. (2006). Pengembangan dan Standarisasi Buku Ajar Kimia untuk SMA/MA Kelas XII Semester 1 Berdasarkan Standar Isi KTSP. Jurnal Penelitian Bidang Pendidikan, 17(1), 38-48 